\title{
Nature Inspired Solutions for Polymers: Will Cutinase Enzymes Make Polyesters and Polyamides Greener?
}

\author{
Valerio Ferrario ${ }^{1}$, Alessandro Pellis ${ }^{2}$, Marco Cespugli ${ }^{1}$, Georg M. Guebitz ${ }^{1,3}$ \\ and Lucia Gardossi 1 ,* \\ 1 Laboratory of Applied and Computational Biocatalysis, Dipartimento di Scienze Chimiche e Farmaceutiche, \\ Università degli Studi di Trieste, Piazzale Europa 1, 34127 Trieste, Italy; valerio.ferrario@gmail.com (V.F.); \\ marco.cespugli@phd.units.it (M.C.); guebitz@boku.ac.at (G.M.G.) \\ 2 Department of Agrobiotechnology, University of Natural Resources and Life Sciences, Vienna, \\ Konrad Lorenz Strasse 20, 3430 Tulln an der Donau, Austria; alessandro.pellis@gmail.com \\ 3 Division of enzymes \& polymers, Austrian Centre of Industrial Biotechnology, Konrad Lorenz Strasse 20, \\ 3430 Tulln an der Donau, Austria \\ * Correspondence: gardossi@units.it; Tel.: +39-040-558-3103
}

Academic Editors: David D. Boehr and Keith Hohn

Received: 31 October 2016; Accepted: 7 December 2016; Published: 13 December 2016

\begin{abstract}
The polymer and plastic sectors are under the urge of mitigating their environmental impact. The need for novel and more benign catalysts for polyester synthesis or targeted functionalization led, in recent years, to an increasing interest towards cutinases due to their natural ability to hydrolyze ester bonds in cutin, a natural polymer. In this review, the most recent advances in the synthesis and hydrolysis of various classes of polyesters and polyamides are discussed with a critical focus on the actual perspectives of applying enzymatic technologies for practical industrial purposes. More specifically, cutinase enzymes are compared to lipases and, in particular, to lipase B from Candida antarctica, the biocatalyst most widely employed in polymer chemistry so far. Computational and bioinformatics studies suggest that the natural role of cutinases in attacking natural polymers confer some essential features for processing also synthetic polyesters and polyamides.
\end{abstract}

Keywords: cutinases; enzymatic polyesters synthesis; green polymer synthesis; enzymatic polymer hydrolysis

\section{Introduction}

There is robust evidence that the next generation of polyesters and polyamides calls for a change of standard aiming at mitigating the environmental impact and natural capital cost of polymer production and processing in general [1,2]. A closer integration between chemistry and biotechnologies is expected to boost the change of the scenario. Due to their remarkable selectivity and catalytic efficiency under mild conditions, enzymes are an attractive and sustainable alternative to toxic catalysts used in the polycondensation of functional monomers such as itaconic acid, which suffer from isomerization or cross-linking under the harsh conditions required by conventional chemical processes that employ organo-catalysts [3]. The possibility to use enzymes for the polyester synthesis has been known since the 1990s and has also been industrially applied by Baxenden Chemicals (UK) for the production, later dismissed, of highly regular structures of polymers. On the other hand, especially for the biomedical sector, enzymatic modification of polyesters represents a milder and selective alternative to chemical or physical treatments aimed at introducing chemical functionalities to the surface of polymers while retaining their bulk properties [2]. 
In nature, cutinases have evolved in some fungi responsible for plant pathologies where these enzymes attack and hydrolyze cutin, a complex hydrophobic polyester. Even though cutinases were discovered more than 40 years ago and tested in a number of technological applications, only more recently have they been proposed as biocatalytic tools for the polymer sector [2]. Indeed, a comprehensive review by Gross et al. published in 2010 discussed the potential of a number of hydrolases to catalyze polyester synthesis through condensation of an array of substrates, focusing the attention on the challenges of the biocatalytic technologies. [4] Out of the 30 synthetic processes reviewed by Gross, 21 were catalyzed by Candida antarctica lipase B (CaLB), an industrial biocatalyst already applied in different chemical and pharmaceutical processes. Only two cases reported the use of one single cutinase, namely Humicola insolens cutinase (HiC). In the light of the most relevant advances of the last five years achieved through the application of cutinases to polymer chemistry, we now present an analysis that extends the focus also to the hydrolysis and functionalization of various classes of polyesters and polyamides. The review intends to provide also a critical comparison between CaLB and the fungal cutinases recently applied in polymer chemistry: HiC, cutinase 1 from Thermobifida cellulosilytica (Thc_cut1) and Fusarium solani pisi cutinase (Fsp). For the first time, the biocatalysts are rationally compared also on the basis of structural, computational, and bioinformatics analysis. Finally, a frank analysis of future perspectives for the practical application of these biocatalysts for productive processes is presented.

\section{The Cutinase Family}

Cutinases (EC 3.1.1.74) are members of the serine hydrolases superfamily comprising the typical Ser-His-Asp catalytic triad and the oxyanion hole, common features shared by other superfamily members such as lipases, esterases, proteases, and amidases [5]. The natural substrate of cutinase is cutin, one of the main polymeric components (together with cutan) of the plant cuticle, which covers all aerial surfaces of higher plants [6,7]. Cutin is a three-dimensional insoluble hydrophobic polyester composed of hydroxyl and hydroxyepoxy fatty acids (usually carrying one to three hydroxyl groups). The most common components of cutin are derivatives of saturated palmitic (C16) or stearic (C18) acid [8]. In vitro, cutinases are able to catalyze ester hydrolysis reactions (in an aqueous environment), as well as esterifications and transesterifications (anhydrous conditions) of large and small molecules. Therefore, they have been proposed as alternative catalysts to lipases and, in particular, to the widely employed and studied lipase B from C. antarctica (CaLB) $[9,10]$.

Since their discovery, cutinases have been investigated for applications in different sectors such as food, chemical, detergent, environmental, and textile industries [11,12]. In the food sector, cutinases are applied for the treatment of cutin-rich vegetables, fruits, and berries to achieve partial cutin hydrolysis and thus improve water permeability, an important parameter for food drying and, ultimately, conservation. Additionally, the increased permeability is exploited for delivering sweeteners, flavor enhancers, preservatives and stabilizer into the fruits or vegetables [5,13]. Cutinases can also be applied for improving the extractability of plant polyphenols from macerated fruit and vegetable materials [14]. Moreover, cutinases can be applied in the flavors industry. In particular, it was reported that Fusarium solani pisi cutinase has a potential for the production of concentrated cheese flavors [15].

In the chemical industry, the synthesis of alkyl esters by cutinases has been reported when used in organic media or low water activity environment. Alkyl esters are essential building blocks for the pharmaceutical and cosmetic sectors. In particular, the selectivity of Fusarium solani pisi cutinase was investigated in the context of the esterification of different alcohols with acids (ethyl butyrate, ethyl oleate, ethyl decanoate, hexyl decanoate, etc.) [16]. The Fusarium solani pisi cutinase was also tested for the production of biodiesel, through the transesterification of small molecules, as well as the synthesis of surfactants $[17,18]$. Cutinases can be utilized in laundry and dishwashing applications as lipolytic enzymes to remove fats. For example, it was shown that the Fusarium solani pisi cutinase is superior in fat removal when compared to the detergent lipase Lipolase ${ }^{\mathrm{TM}}$ [19]. Cutinases are also used in detergents for de-pilling during washing of polyester fabrics [1]. The Fusarium solani pisi cutinase 
has been also suggested for the degradation of various phthalates, such as dipentyl phthalate, butyl benzyl phthalate, and di-(2-ethylhexyl)-phthalate by ester hydrolysis [20-22]. In the textile industry, cutinases have been applied for the hydrolysis of the cutin residues on natural fibers such as cotton and wool. Cutin removal improves the wettability of the fiber, which then facilitates uniform dyeing and finishing. Cutinases from Pseudomonas mendocina, from Fusarium solani pisi and from Thermobifida fusca were widely tested for this purpose [23].

Cutinases are produced by plants, bacteria, and fungi (commonly phytopathogenic). Plant cutinases are less investigated since their isolation, maintenance, and cultivation are much more complicated when compared to the microbial analogs [6]. Fungal cutinases are extracellular enzymes expressed and secreted for the cutin hydrolysis during plant infection, where the cuticle depolymerization represents one of the first steps [24]. Fatty acids released during enzymatic hydrolysis of cutin represent a carbon source for cellular growth [6]. The first isolated cutinase was purified already in the 1970s from the Fusarium solani growing on cutin as a sole carbon source [25]. Nevertheless, this enzyme class is still relatively 'young' with just few members that have been deeply investigated for their catalytic potential. Cutinases have been subsequently isolated, often recombinantly expressed and characterized from different microorganisms. Microbial cutinases currently isolated and characterized with a known gene sequence and molar masses are listed in Table 1.

Table 1. Isolated and characterized microbial cutinases. For each entry the microbial source is indicated as well as the molar masses.

$\left.\begin{array}{ccc}\hline \text { Source } & \text { Molar Masses (kDa) } & \text { Ref. } \\ \hline \text { Alternaria brassicicola } & 26 & {[26]} \\ \text { Aspergillus nidulans } & 29 & {[27]} \\ \text { Aspergillus niger } & 22.8 & {[28]} \\ \text { Aspergillus oryzae } & 19.6 & {[29]} \\ \text { Botrytis cinerea } & 18 & {[30]} \\ \text { Colletotrichum capsici } & 23.7 & {[31]} \\ \text { Colletotrichum gloeosporioides } & 40 & {[32]} \\ \text { Colletotrichum kahawae } & 21 & {[32]} \\ \text { Coprinopsis cinerea } & 29.6 & {[33]} \\ \text { Cryptococcus sp. } & 21.2 & {[34]} \\ \text { Fusarium oxysporum } & 23.4 & {[35]} \\ \text { Fusarium roseum culmorum } & 24.3 & {[36]} \\ \text { Fusarium solani } & 20.8 & {[37]} \\ \text { Glomerella cingulata } & 21.1 & {[38]} \\ \text { Helminthosporium sativum } & 25 & {[39]} \\ \text { Humicola insolens } & 20.3 & {[40]} \\ \text { Magnaporthe grisea } & 24.3 & {[41]} \\ \text { Monilinia fructicola } & 18.6 & {[42]} \\ \text { Pennicillium citrinum } & 14.1 & {[43]} \\ \text { Pseudomonas putida } & 30 & {[44]} \\ \text { Pyrenopeziza brassicae } & 21 & {[45]} \\ \text { Rhizoctonia solani } & 19.8 & {[46]} \\ \text { Saccharomonospora virdis } & 30.3 & {[47]} \\ \text { Thermobifida alba } & 33.5 & {[48]} \\ \text { Thermobifida cellulosilytica } & 30.8 & {[10]} \\ \text { Thermobifida fusca } & 30.8 & {[49]} \\ \text { Thielavia terrestris } & 27 & {[50]} \\ \text { Trichoderma reesei } & 21.7 & {[51]} \\ \text { Tropaeolum majus } & {[53]} \\ \text { Venturia inaequalis } & & \\ & & \end{array}\right]$

From the structural point of view, cutinases are the smallest family of the $\alpha / \beta$ hydrolases superfamily [6]. Considering their biocatalytical use as lipase alternatives, differences and similarities of these two enzyme classes have been recently investigated with the aid of computational 
methodologies. Cutinases and lipases share, as a common feature, the hydrophobicity of their surface, as a consequence of the insolubility of their natural substrates [10]. Unlike CaLB and most lipases, the catalytic Ser of cutinases is not buried into a deep funnel shape active site, rather the active site is superficial and accessible to solvents and substrates even in absence of any hydrophobic interface [10]. In addition, the active site accessibility of most lipases is regulated by conformational changes involving the lid domain which exposes the active site upon interfacial activation [54]. In this sense, cutinases appear to be more similar to $C$. antarctica lipase B (CaLB) (Figure 1) which is considered as an unconventional lipase also because it lacks the mobile lid which is not susceptible to any relevant structural rearrangements [54]. On that respect, the dynamic behavior of two cutinases, namely Humicola insolens cutinase (HiC) and cutinase 1 from Thermobifida cellulosilytica (Thc_cut1) were compared with CaLB by performing MD simulations in explicit water and toluene environments [10]. The study confirmed similarities in the dynamic behavior of CaLB and Thc_cut1 since both enzymes had really stable scaffold in both simulated solvents. On the other hand, $\mathrm{HiC}$ showed two flexible domains (Figure 1c) able to influence the active site accessibility which is similar to the behavior of other typical lipases [10]. A similar "breath-like" movement at the active site opening was also pointed out for the cutinase from Fusarium solani [37].
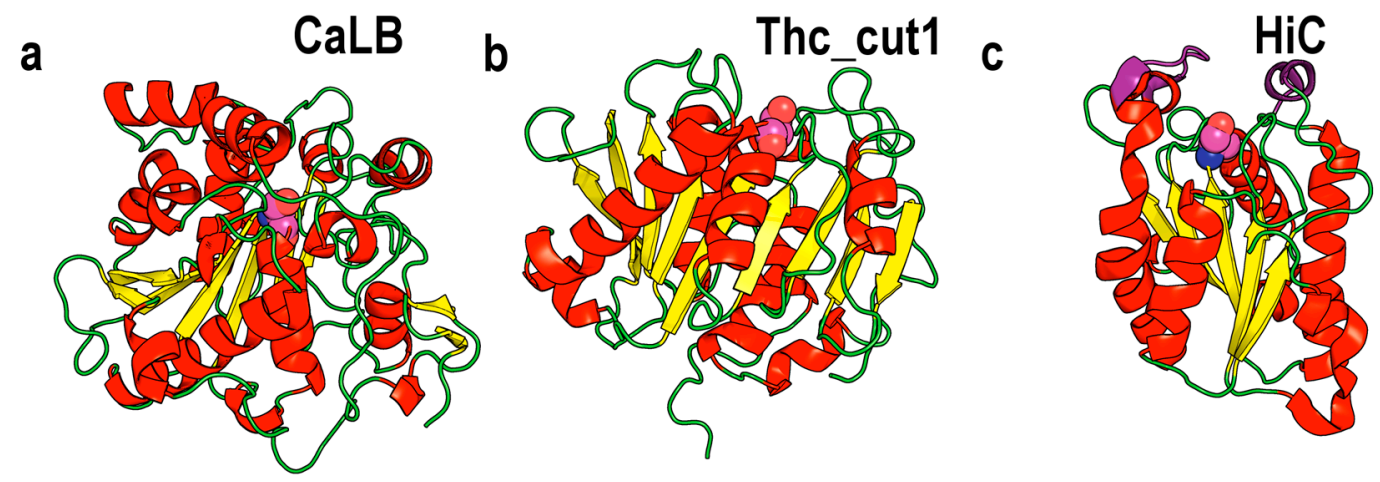

Figure 1. Representation of the 3D structures of two cutinases in comparison with CaLB: (a) CaLB (PDB 1TCA); (b) Thc_cut1 (Homology model); (c) HiC (PDB 4OYY). Structures are represented in cartoon mode and colored according to their secondary structure; the catalytic serine of each enzyme is highlighted in sphere mode. The mobile domains affecting active site accessibility of HiC are colored in violet.

Similarities between CaLB and Thc_cut1 are not just limited to their surface properties and dynamic behavior but are also evident by considering their active site properties. Features such as ability of establishing $\mathrm{H}$ bonds and hydrophobic-hydrophilic balance were recently analyzed quantitatively by means of a bioinformatics method based on BioGPS molecular descriptors (Global Positioning System in Biological Space) and multivariate statistical analysis $[55,56]$. The method allows for functional structural correlation by comparing three-dimensional structures rather than protein sequences, and it makes any structural alignment unnecessary. The bioinformatic analysis pointed out how two cutinases, HiC and Thc_cut1, are classified in between the lipase and esterase families [56]. Accordingly, cutinases are not just active on cutin, but they also hydrolyze suberin (a "waxy" polyester and main component of cork) and are also able to hydrolyze a variety of synthetic esters and show activity on short- and long-chains of emulsified triacylglycerols [6]. Moreover, in analogy to lipases and esterases, when applied in low water activity environment, cutinases are also able to catalyze esterification and transesterification reactions [56].

\section{Cutinases as Biocatalysts for Polymerization Reactions}

For several decades, the demand for polymers and plastics has grown at a faster rate than for any other group of bulk materials, and expectations are that this trend will continue until 
2020. Biocatalytical strategies are promising solutions to mitigate the environmental impact of polymerization technologies currently used [2].

Enzymes are attractive sustainable alternatives to toxic catalysts traditionally used in polymerization reactions, such as metal catalysts and tin in particular. The objective of enzymatic polymerization is not the synthesis of high molecular weight polymers but rather opportunity to produce functionalized as well biodegradable polymers with controlled architecture through highly selective processes at mild temperatures ranging between 40 and $90{ }^{\circ} \mathrm{C}$, whereas conventional polymerizations are carried out at $T>150^{\circ} \mathrm{C}$ with particular reference to organo-catalysts employed in the production of itaconic acid polyesters [56,57]. Enzymatic synthesis generally leads to polymers with moderate molar masses when compared to products obtainable via conventional chemical synthesis, but this drawback has been circumvented by using a two-step procedure, where an initial enzymatic polymerization leads to oligomers and a second step is carried out at higher temperature and/or lower pressure after removal of the biocatalyst [2]. Furthermore, the synthesis of oligomers and short telechelics pre-polymers with functional ends represents an effective strategy for obtaining polymers with higher molecular weight [58].

Actually, most of the studies related to enzymatic polymerization make use of lipases, and in particular CaLB which is one of the most widely used enzymes in industry and the 'yardstick' for comparison in academia [3,59].

The use of cutinases HiC, Fsp, and Thc_cut1 for polymerization reactions was explored only in the last decade in synthetic reactions reported in Figure 2.

Cutinase-catalyzed polycondensation was reported for the first time in 2007, when HiC was used for polyester synthesis using different diacids and diols [60]. Polycondensation reactions were performed in solvent-free environment and under vacuum $(10 \mathrm{~mm} \mathrm{Hg})$ at $70{ }^{\circ} \mathrm{C}$ using an adsorbed preparation of $\mathrm{HiC}$ on previously lyophilized Lewatit beads (similar to the commercial preparation Novozym ${ }^{\circledR} 435$ where CaLB is adsorbed on the same polymeric carrier) [60]. In particular, adipic acid was tested in polycondensation reactions with 1,4-butanediol, 1,6-hexanediol, and 1,8-octanediol (Figure 2a) leading to $\mathrm{M}_{\mathrm{n}}$ ranging from 2700 to 12,000 Da. A more rigid diol, 1,4-cyclohexanedimethanol, was polymerized with adipic, succinic, suberic, and sebacic acids (from $\mathrm{C}_{4}$ to $\mathrm{C}_{10}$ ) (Figure $2 \mathrm{~b}$ ) leading to $\mathrm{M}_{\mathrm{n}}$ from 900 to $19,000 \mathrm{Da}$ according to the diacid chain lenght [60]. Results demonstrated the ability of $\mathrm{HiC}$ to perform polycondensation with each tested monomer and showed a preference for longest acids or diols chains: adipic acid with 1,8-butanediol and 1,4-cyclohexanedimethanol with sebacic acid gave higher polymerization degrees. In the same work, $\mathrm{HiC}$ was also reported able to perform ring-opening polymerizations of lactones both in toluene and in solvent-free conditions (Figure 3) leading to polymers with $M_{n}$ of 24,900 and 16,000 Da respectively.

In another publication, where HiC was covalently immobilized on Amberzyme oxirane, the preference of $\mathrm{HiC}$ for long chain substrates was confirmed. Its selectivity was compared again with the commercial preparation of CaLB Novozym ${ }^{\circledR} 435$ which shows higher substrate promiscuity; moreover, $\mathrm{HiC}$ proved to be able to perform homo-polymerization of $\omega$-hydroxyalkanoic acids (Figure 2c) [61]. 


\section{Cutinase-catalyzed Polycondensation reactions}

a) Polyesters from diacids/diesters and linear diols

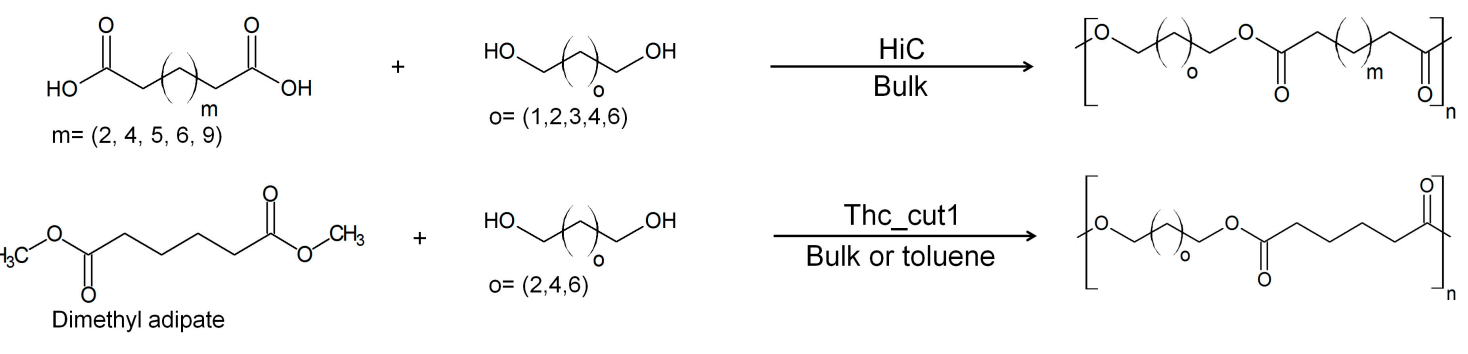

b) Polyesters from diacids and cyclic diols

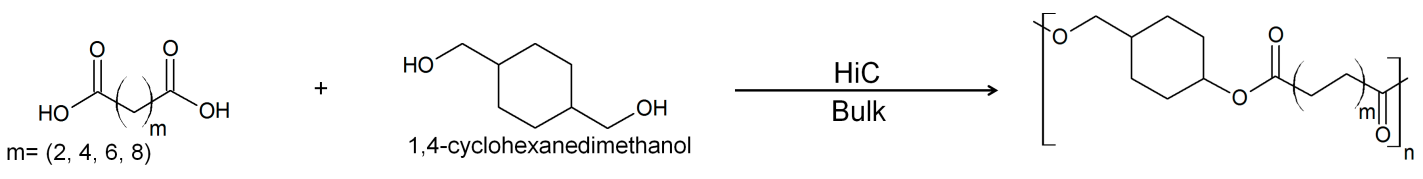

c) Polyesters from w-hydroxyalkanoic acids<smiles>O=C(O)CCCCCCCO</smiles>

$\mathrm{HiC}$

Diphenyl ether

$\mathrm{m}=(2,6,8,12)$

d) Polyamides from diesters and linear diamines

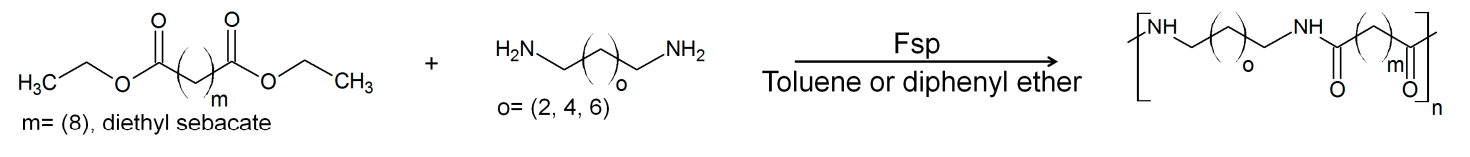

e) Polyamides from aliphatic and aromatic monomers
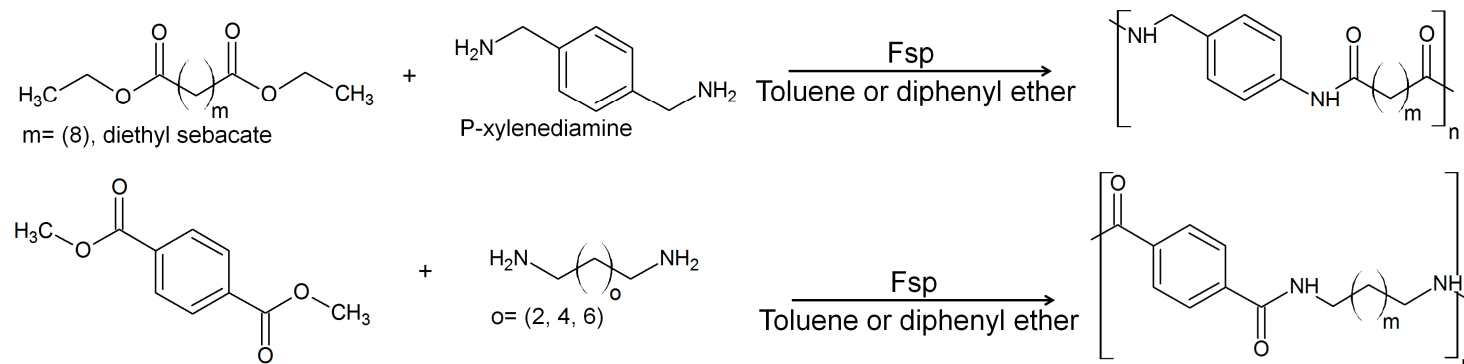

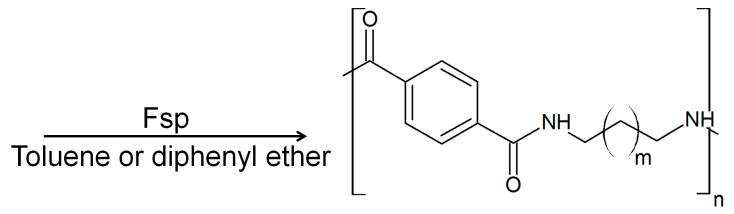

Dimethyl terephthalate<smiles>COC(=O)c1ccc(C(=O)NCc2ccc(CN)cc2)cc1</smiles>

Figure 2. Schematic representation of polymer synthesis catalyzed by the different cutinases and discussed in the present section. Fsp: Fusarium solani pisi cutinase; HiC: Humicola insolens cutinase; Thc_cut1: Thermobifida cellulosilytica cutinase 1. (a) polyesters from diacids/diesters and linear diols; (b) polyesters from diacids and cyclic diols; (c) polyesters from $\omega$-hydroxyalkanoic acids; (d) polyamides from diesters and linear diamines; (e) polyamides from aliphatic and aromatic monomers. 


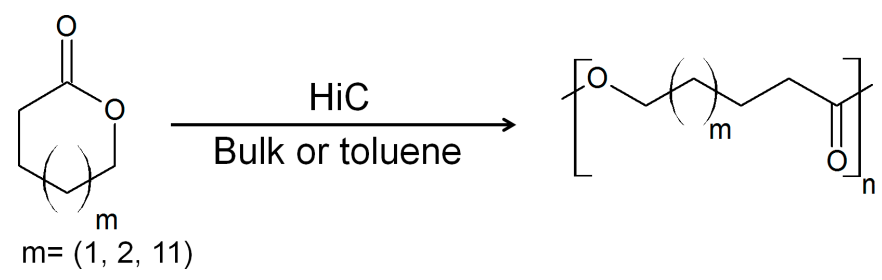

Figure 3. Schematic representation of Ring Opening Polymerizations (ROP) catalyzed by HiC both in toluene and solvent free conditions.

More recently, the activities of $\mathrm{CaLB}$ and $\mathrm{HiC}$ were also compared with another cutinase, namely Thc_cut1. Both HiC and Thc_cut1 were covalently immobilized on EC-EP Sepabeads as well as CaLB which was also employed in its commercial preparation (Novozym ${ }^{\circledR} 435$ ) [10]. All the biocatalysts were tested for polycondensation of dimethyl adipate with 1,4-butanediol or 1,8-octanediol using a thin film solvent-free system under reduced pressure $(100 \mathrm{kPa})$ at $70{ }^{\circ} \mathrm{C}$ (Figure 2a). The best performances in terms of conversion and molar masses of the products were obtained by using Thc_cut 1 that led to a $86 \%$ monomer conversion and $M_{n}$ of around 1000 Da while CaLB gave a conversion of $76 \%$ and a $M_{n}$ of only $528 \mathrm{Da}$ [10]. Interestingly, the polycondensation catalyzed by HiC gave no observable products, in disagreement to what was previously reported [60]. The substrate acceptance of Thc_cut1 was further investigated, catalyzing the polycondensations of dimethyl adipate with 1,4-butanediol, 1,6-hexanediol, 1,8-octanediol, and 1,12-dodecandiol [10]. It is noteworthy that, in solvent-free conditions, Thc_cut1 showed a preference for short chain diol and the reaction with 1,4-butanediol gave better conversions; on the other hand, the same tests with 1,4-butanediol, 1,6-hexanediol, and 1,8-octanediol were repeated using toluene as solvent produced very similar results in terms of reaction conversion (around 18\% after $24 \mathrm{~h}$ of reaction), indicating that the higher conversion with 1,4-butanediol might be induced by viscosity and mass transfer effect which have to be carefully considered in this kind of investigation. The attenuation of the mass transfer issues using a solvent demonstrated indeed that Thc_cut1 does not have relevant preference in the use of 1,4-butanediol, 1,6-hexanediol, and 1,8-octanediol [10,56]. Furthermore, a new enzyme preparation, where Thc_cut1 was immobilized on a fully renewable support based on rice husk, was used for the polycondensation of dimethyl adipate with 1,4-butanediol and 1,8-octanediol. The reaction conditions were optimized by a fractional factorial design and finally, such Thc_cut1 preparation was able to reach conversions, considering monomer consumption, as high as $89 \%$ [56]. Also, it is remarkable to note that the activity of Thc_cut1 did not decrease after lyophilization.

CaLB was also compared with Fsp in a different polymerization reaction for the obtainment of polyamides. CaLB was tested in its commercial form (Novozym ${ }^{\circledR} 435$ ), while Fsp was adsorbed on Lewatit beads (similar to Novozym ${ }^{\circledR} 435$ ) and as CLEA (Cross Linked Enzyme Aggregates) [62]. Fsp and CaLB were able to catalyze polyamide formation of diethyl sebacate with 1,8-diaminooctane, 1,6-hexanediamine and 1,4-butanediamine (Figure 2d). The assays were conducted at $70{ }^{\circ} \mathrm{C}$ using toluene or diphenyl ether as solvents. The best conversions were obtained by CLEA Fsp ( $>50 \%)$ followed by CaLB (around 45\%), whereas Fsp adsorbed on Lewatit gave lower monomer conversions $(<25 \%)$ [62]. The same enzyme preparations were also tested for the polymerization of aromatic amides: enzymatic syntheses of oligo(p-xylylene sebacamide) and oligo(octamethylene terephthalamide) were successfully performed whereas in this case, CaLB led to better products than CLEA Fsp when 1,8-diaminoctane was used as diamine (Figure 2e) [63].

In general, the immobilization of the biocatalyst is mandatory in these synthetic processes for several reasons: (1) to avoid the aggregation of the hydrophilic enzyme molecules; (2) to recycle the expensive enzyme; and (3) to prevent the contamination of product by the enzyme protein [2,3]. Considering the data reported in literature, it must be noted that results in terms of molecular weight of polymerization products might be affected by detachment and dispersion of the enzyme when not covalently supported as demonstrated in previous studies [64]. In addition to adsorbed preparation 
with consequently problematic leaching, the mechanical strength of CLEAs preparations still has to be demonstrated on an industrially relevant scale [65].

A critical parameter in the performance of an immobilized enzyme is indeed the spatial distribution of the enzyme and substrate within a macroporous resin. The enzyme distribution of CaLB immobilized within a macroporous polymer matrix revealed that the enzyme is localized in an external shell of the bead with a thickness of $\sim 100 \mu \mathrm{m}$. Furthermore, it was found that CaLB secondary structure was not altered by immobilization.

Unlike CaLB, polystyrene molecules of similar molecular weight diffuse easily throughout Novozym 435 beads. Scanning Electron Micrograph (SEM) images of the beads showed that the average pore size is 10 times larger than CaLB or polystyrene molecules, implying that there is no physical barrier to enzyme or substrate diffusion throughout the beads [65].

In the case of enzymatic polycondensation and more specifically in solvent-free systems, the viscosity of reaction mixtures makes the diffusion of substrates and pre-polymers into the pores highly unlikely [59]. The porosity of carriers seems to play a negligible role in the process design, rather, porosity might induce the risk of undesired occlusion by substrates and products, thus limiting the efficiency of the enzyme. This assumption is also supported by recent data obtained in polycondensation catalyzed by hydrolases immobilized on rice husk $[59,66]$. Although the enzymes (CaLB and Thc_cut1) were immobilized only on the surface either through adsorption-crosslinking or covalent bonding, the polyester synthesis proceeded with comparable rates and conversion as in the case of the macroporous methacrylic resins. Indeed, it was demonstrated that the most efficient reaction systems for biocatalyzed viscous reactions employed enzymes homogeneously dispersed on large volumes of carriers.

\section{Cutinases as Biocatalysts for Polymers Hydrolysis}

The ability of some enzymes to hydrolyze polymer molecules is under investigation as a possible solution for the increasing awareness of the world-wide problems associated with plastic pollution since conventional chemical recycling approaches are energy-consuming and cost-intensive methods requiring large-scale degradation processes for an economical application [67]. On the other hand, the ability of enzymes to hydrolyze polymers can be exploited for structural fine-tuning and for controlling the degree of polymer functionalization by operating under mild conditions [57]. The possibility to perform partial hydrolysis on the outer layer of the polymer can be exploited for changing the superficial properties in terms of hydrophobicity/hydrophilicity balance, obtaining reactive groups for successive modifications, and changing the polymer biocompatibility just to name a few [68-70].

The ability of some lipases to hydrolyze polyesters has been known since 1967, and among them, the most widely used and studied one is again the lipase B from C. antarctica (CaLB) [2,71]. During the last 10 years, with the aim to expand the biocatalytical tools for polymer hydrolysis and modification, several cutinases have been tested for their ability to hydrolyze polyesters (Table 2).

Table 2. Polyesters and polyamides that were hydrolyzed via cutinase-catalyzed reactions.

\begin{tabular}{ccc}
\hline Polymer & Enzyme & Ref. \\
\hline & Thermobifida cellulosilytica & {$[72,73]$} \\
\cline { 2 - 3 } & Thermobifida fusca & {$[67]$} \\
\cline { 2 - 3 } Poly(ethylene terephthalate) (PET) & Thermobifida alba & Thielavia terrestris \\
\cline { 2 - 3 } & $\begin{array}{l}\text { Humicola insolens } \\
\text { Pseudomonas mendocina } \\
\text { Fusarium solani }\end{array}$ & {$[75]$} \\
\cline { 2 - 3 } & Penicillum mendocin & \\
& Penicillum citrinum & {$[69,74]$} \\
\hline
\end{tabular}


Table 2. Cont.

\begin{tabular}{ccc}
\hline Polymer & Enzyme & Ref. \\
\hline Poly(L-lactic acid) (PLA) & $\begin{array}{c}\text { Humicola insolens } \\
\text { Thermobifida halotolerans }\end{array}$ & {$[70,76]$} \\
& Thermobifida cellulosilytica & {$[78]$} \\
\hline Poly(ethylene furanoate) (PEF) & Humicola insolens & {$[79]$} \\
\hline Poly(butylene adipate-co-terephthalate) (PBAT) & Thermobifida cellulosilytica & \\
\hline Poly(caprolactone) (PCL) & Thielavia terrestris & {$[79]$} \\
\hline & Thielavia terrestris & \\
Poly(butylene succinate) (PBS) & $\begin{array}{c}\text { Aspergillus oryzae } \\
\end{array}$ & Fusarium solani \\
& Humicola insolens & {$[79]$} \\
\hline Polyamide 6,6 & Alternaria brassicicola & \\
\hline
\end{tabular}

The scientific work was focused on the hydrolysis of the most relevant industrial polymers, in particular poly(ethylene terephthalate) (PET). Cutinases from various Thermobifida species demonstrated a good selectivity on PET [72,73]. More in detail, cutinases from Thermobifida cellulosilytica, Thermobifida fusca, and Thermobifida alba demonstrated an ability to hydrolyze PET. Even though all these Thermobifida cutinases turned out to be very similar in their sequences, they differed in PET hydrolysis activities. Besides, it is important to notice that products released from PET hydrolysis were shown to have an inhibitory effect on the activity of Thermobifida fusca cutinase [67]. In addition, modeling analysis suggests that the hydrolysis efficiencies among Thermobifida cutinases are influenced by the electrostatic properties in the enzyme regions surrounding the active site entrance, thus affecting the essential sorption processes on the water-insoluble PET [81]. In that respect, with the aim of improving the hydrolytic performances of the cutinase 1 from Thermobifida cellulosilytica against PET, the polyhydroxyalkanoate binding module from Alcaligenes faecalis was fused to the cutinase obtaining a three-fold increase of the PET hydrolysis release products [81]. The validity of such an approach was further confirmed by other mutagenesis experiments where the regions in proximity to the active site of cutinases from Thermobifida fusca and from Fusarium solani pisi were mutated for changing the superficial hydrophobicity: mutants turned out to have improved PET hydrolytic performances [82,83]. Other cutinases able to perform PET hydrolysis are those from Humicola insolens, Thielavia terrestris, Pseudomonas mendocina, and Penicillum citrinum [69,74]. Notably, Humicola insolens cutinase demonstrated high hydrolytic activity due to its stability after prolonged incubation at $70{ }^{\circ} \mathrm{C}$, which corresponds to an optimal hydrolysis temperature, being very close to the $T_{\mathrm{g}}$ of PET. At this temperature, the enzyme benefits from higher mobility of the polyester chains in the amorphous phase, thus increasing the enzyme accessibility to the ester bonds [67]. The most commonly used conditions are enzyme concentrations between 2 and $5 \mu \mathrm{M}$ and T ranging from 50 to $70{ }^{\circ} \mathrm{C}$, depending on the enzyme thermal stability.

Just a few reports investigate the hydrolysis of different polymers using cutinases. Among them, cutinase 1 from Thermobifida cellulosilytica was able to successfully hydrolyze poly(ethylene furanoate) (PEF), new environmentally-friendly polyesters [78]. The cutinase from Thielavia terrestris was reported to hydrolyze also poly(caprolactone) and poly(butylene succinate) (PBS) at a rate of $203 \mathrm{mg} / \mathrm{h}$ per $\mathrm{mg}$ of protein, and $56 \mathrm{mg} / \mathrm{h}$ per $\mathrm{mg}$ of protein, respectively [74]. Hydrolytic activities on PBS were reported also for cutinases from Fusarium solani, from Aspergillus oryzae, from Alternaria brassicicola, and from Humicola insolens [74]. The latter was also reported to be active in the hydrolysis of poly(lactic acid) as well as cutinases from Thermobifida halotolerans [70,77]. Finally, cutinase from Fusarium solani is currently reported as the only cutinase able to hydrolyze Polyamide 6,6 [80]. 


\section{Conclusions and Future Perspectives}

The polymer industry is under pressure to innovating towards more sustainable processes and enzymes represent a formidable tool for conferring unique targeted properties to polyesters and polyamides, while meeting greener criteria. Nevertheless, the replacement of conventional catalysts and chemical synthetic methodologies with biocatalysts on an industrial scale has not taken place yet, since enzymatic processes require to be further optimized both in terms of economic and technological performances. After more than one decade of extensive investigations of the application of lipase CaLB in polyester/polyamide synthesis and modification, recent studies showed that cutinases are endowed with specific properties that make such enzymes promising biocatalysts for translating lab reactions into processes of practical and industrial relevance.

Computational and bioinformatics investigations disclosed how cutinases represent an enzyme class in between lipases and esterases. Interestingly, the same is also applicable to C. antarctica lipase B, suggesting, for the first time, some criteria for identifying biocatalysts applicable to polyester synthesis and hydrolysis. In the case of cutinases, the wider and more accessible active site, along with differences in terms of substrate specificity efficiency under milder and less strictly anhydrous conditions represent crucial features for succeeding in the hard task of producing highly structured and effective polyesters on industrial scale.

However, when cutinases are compared to lipases and CaLB in particular, it is important to consider that industry has been making wide use of lipases-especially in detergent formulations-for several decades, therefore pushing the scientific research towards the optimization of stability, activity, and expression of these biocatalysts. Similar efforts would be needed for transforming selected promising cutinases into efficient industrial catalysts. The use of cutinases for the mild and controlled hydrolysis and functionalization of polymer surfaces will get closer to an industrial scale when the expression and the selection of the best variants (deriving from rational design or directed evolution) will be optimized and scaled for tailored applications on commercial polymers.

Furthermore, studies are still needed to verify the applicability of cutinases to a wide array of substrates of industrial interest, such as sensitive functionalized moieties for the obtainment of higher-value polymers carrying lateral functionalities, or renewable monomers for the production of biobased polymers for the cosmetic and the pharmaceutical industry where the obtainment of short oligomers is desired in order to be utilized in various formulations (e.g., nano capsules) [84]. Processes catalyzed by enzymes and whole cells will, in the coming years, be major players for global sustainability. In this sense, the industrial need of robust and heterogeneous biocatalysts to be recovered and reused makes immobilization procedures a key step of practical relevance; it is noteworthy that, also in the perspective of substituting petrol-based carriers that are currently on the market, immobilization technologies recently developed with cheap, stable, and renewable rice husks are of particular interest [66].

In conclusion, cutinases represent promising and selective biocatalytic tools for polyester chemistry, but their potentials still need to be fully exploited through an industrially driven perspective. In an industry moving more and more towards a circular economy [85] and an atomic economy where each compound derived from the process needs to be recycled, enzymes and whole cell transformations will, in the coming years, be a major player for global sustainability.

Acknowledgments: Valerio Ferrario is grateful to MIUR (Ministero dell'Istruzione, dell'Università e della Ricerca-Roma) and to Università degli Studi di Trieste for financial support. Lucia Gardossi acknowledges EU COST Action CM1303 System Biocatalysis for financial support. This work has been supported by the Federal Ministry of Science, Research and Economy (BMWFW), the Federal Ministry of Traffic, Innovation and Technology (bmvit), the Styrian Business Promotion Agency SFG, the Standortagentur Tirol, the Government of Lower Austria and Business Agency Vienna through the COMET-Funding Program managed by the Austrian Research Promotion Agency, FFG.

Author Contributions: V.F., A.P., and M.C. wrote the paper, G.M.G. and L.G. conceived and corrected the manuscript.

Conflicts of Interest: The authors declare no conflict of interest. 


\section{References}

1. Guebitz, G.M.; Cavaco-Paulo, A. Enzymes go big: Surface hydrolysis and functionalisation of synthetic polymers. Trends Biotechnol. 2008, 46, 32-38. [CrossRef] [PubMed]

2. Pellis, A.; Herrero Acero, E.; Ferrario, V.; Ribitsch, D.; Guebitz, G.M.; Gardossi, L. The closure of the cycle: Enzymatic synthesis and functionalization of bio-based polyesters. Trends Biotechnol. 2016, 34, 316-328. [CrossRef] [PubMed]

3. Pellis, A.; Herrero Acero, E.; Gardossi, L.; Ferrario, V.; Guebitz, G.M. Renewable building blocks for sustainable polyesters: New biotechnological routes for greener plastics. Polym. Int. 2016, 65, 861-871. [CrossRef]

4. Gross, R.A.; Ganesh, M.; Lu, W. Enzyme-catalysis breathes new life into polyester condensation polymerizations. Trends Biotechnol. 2010, 28, 435-443. [CrossRef] [PubMed]

5. Nyyssola, A. Which properties of cutinases are important for applications? Appl. Microbiol. Biotechnol. 2015, 99, 4931-4942. [CrossRef] [PubMed]

6. Dutta, K.; Sen, S.; Veeranki, V.K. Production, characterization and applications of microbial cutinases. Proc. Biochem. 2009, 44, 127-134. [CrossRef]

7. Briggs, D.E.G. Molecular taphonomy of animal and plant cuticles: Selective preservation and diagenesis. Philos. Trans. R. Soc. B 1999, 354, 7-17. [CrossRef]

8. Kolattukudy, P.E. Polyesters in higher plants. Adv. Biochem. Eng. Biotechnol. 2001, 71, 1-4. [PubMed]

9. Gross, R.A. Overview: Polyester synthesis catalyzed by Candida antarctica lipase B and the cutinase from Humicola insolens. Polym. Prepr. 2006, 47, 263-264.

10. Pellis, A.; Ferrario, V.; Zartl, B.; Brandauer, M.; Gamerith, C.; Herrero Acero, E.; Ebert, C.; Gardossi, L.; Guebitz, G.M. Enlarging the tools for efficient enzymatic polycondensation: Structural and catalytic features of cutinase 1 from Thermobifida cellulosilytica. Catal. Sci. Technol. 2016, 6, 3430-3442. [CrossRef]

11. Carvalho, C.M.L.; Aires-Barros, M.R.; Cabral, J.M.S. Cutinase structure, function and biocatalytic applications. Electron. J. Biotechnol. 1998, 1, 160-173. [CrossRef]

12. Carvalho, C.M.L.; Aires-Barros, M.R.; Cabral, J.M.S. Cutinase: From molecular level to bioprocess development. Biotechnol. Bioeng. 1999, 66, 17-34. [CrossRef]

13. Poulose, A.; Boston, M. Enzyme Assisted Degradation of Surface Membranes of Harvested Fruits and Vegetables. U.S. Patent 5,298,265, 29 March 1994.

14. Andersen, K.E.; Borch, K.; Krebs, L.N.E.; Steffen, E.; Landvik, S.; Schnorr, K.M. Plant Extraction Process. WO Patent 2,006,111,163, 26 October 2006.

15. Regado, M.A.; Cristóvão, B.M.; Moutinho, C.G.; Balcão, V.M.; Aires-Barros, R.; Ferreira, J.P.M.; Xavier Malcata, F. Flavour development via lipolysis of milkfats: Changes in free fatty acid pool. Int. J. Food Sci. Technol. 2007, 42, 961-968. [CrossRef]

16. De Barros, D.P.C.; Fonseca, L.P.; Cabral, J.M.S.; Weiss, C.K.; Landfester, K. Synthesis of alkyl esters by cutinase in miniemulsion and organic solvent media. Biotechnol. J. 2009, 4, 674-683. [CrossRef] [PubMed]

17. Badenes, S.M.; Lemos, F.; Cabral, J.M.S. Transesterification of oil mixtures catalyzed by microencapsulated cutinase in reversed micelles. Biotechnol. Lett. 2010, 32, 399-403. [CrossRef] [PubMed]

18. Badenes, S.M.; Lemos, F.; Cabral, J.M.S. Kinetics and mechanism of the cutinase-catalyzed transesterification of oils in AOT reversed micellar system. Bioprocess. Biosyst. Eng. 2011, 34, 1133-1142. [CrossRef] [PubMed]

19. Flipsen, J.A.C.; Appel, A.C.M.; van der Hijden, H.T.W.M.; Verrips, C.T. Mechanism of removal of immobilized triacylglycerol by lipolytic enzymes in a sequential laundry wash process. Enzym. Microb. Technol. 1998, 23, 274-280. [CrossRef]

20. Ahn, J.Y.; Kim, Y.H.; Min, J.; Lee, J. Accelerated degradation of dipentyl phthalate by Fusarium oxysporumf. sp. pisi cutinase and toxicity evaluation of its degradation products using bioluminescent bacteria. Curr. Microbiol. 2006, 52, 340-344. [PubMed]

21. Kim, Y.H.; Lee, J.; Ahn, J.Y.; Gu, M.B.; Moon, S.H. Enhanced degradation of an endocrine-disrupting chemical, butyl benzyl phthalate, by Fusarium oxysporum f. sp. pisi cutinase. Appl. Environ. Microbiol. 2002, 68, 4684-4688. [CrossRef] [PubMed]

22. Kim, Y.H.; Lee, J.; Moon, S.H. Degradation of an endocrine disrupting chemical, DEHP [di-(2-ethylhexyl)phthalate], by Fusarium oxysporum f. sp. pisi cutinase. Appl. Microbiol. Biotechnol. 2003, 63, 75-80. [CrossRef] [PubMed] 
23. Chen, S.; Su, L.; Chen, J.; Wu, J. Cutinase: Characteristics, preparation, and application. Biotechnol. Adv. 2013, 31, 1754-1767. [CrossRef] [PubMed]

24. Soliday, C.L.; Kolattukudy, P.E. Primary structure of the active site region of fungal cutinase, an enzyme involved in phytopathogenesis. Biochem. Biophys. Res. Commun. 1983, 114, 1017-1022. [CrossRef]

25. Purdy, R.E.; Kolattukudy, P.E. Hydrolysis of plant cuticle by plant pathogens. Properties of cutinase I, cutinase II, and a nonspecific esterase isolated from Fusarium solani pisi. Biochemistry 1975, 14, 2832-2840. [CrossRef] [PubMed]

26. Yao, C.; Köller, W. Diversity of cutinases from plant pathogenic fungi: Different cutinases are expressed during saprophytic and pathogenic stages of Alternaria brassicicola. Mol. Plant Microbe Interact. 1995, 8, 122-130. [CrossRef]

27. Castro-Ochoa, D.; Peña-Montes, C.; González-Canto, A.; Alva-Gasca, A.; Esquivel-Bautista, R.; Navarro-Ocaña, A.; Farrés, A. An extracellular cutinase from Aspergillus nidulans induced by olive oil. Appl. Biochem. Biotechnol. 2012, 166, 1275-1290. [CrossRef] [PubMed]

28. Nyyssölä, A.; Pihlajaniemi, V.; Järvinen, R.; Mikander, S.; Kontkanen, H.; Kruus, K.; Kallio, H.; Buchert, J. Screening of microbes for novel acidic cutinases and cloning and expression of an acidic cutinase from Aspergillus niger CBS 513.88. Enzym. Microb. Technol. 2013, 52, 272-278. [CrossRef] [PubMed]

29. Maeda, H.; Yamagata, Y.; Abe, K.; Hasegawa, F.; Machida, M.; Ishioka, R.; Gomi, K.; Nakajima, T. Purification and characterization of a biodegradable plastic-degrading enzyme from Aspergillus oryzae. Appl. Microbiol. Biotechnol. 2005, 67, 778-788. [CrossRef] [PubMed]

30. Shishiyama, J.; Araki, F.; Akai, S. Studies on cutin-esterase II. Characteristics of cutin-esterase from Botrytis cinerea and its activity on tomato-cutin. Plant Cell Physiol. 1970, 11, 937-945.

31. Ettinger William, F.; Thukral Sushi, K.; Kolattukudy Pappachan, E. Structure of cutinase gene, cDNA, and the derived amino acid sequence from phytopathogenic Fungi. Biochemistry 1987, 26, 7883-7892. [CrossRef]

32. Chen, Z.; Franco, C.F.; Baptista, R.P.; Cabral, J.M.S.; Coelho, A.V.; Rodrigues, C.J.; Melo, E.P. Purification and identification of cutinases from Colletotrichum kahawae and Colletotrichum gloeosporioides. Appl. Microbiol. Biotechnol. 2007, 73, 1306-1313. [CrossRef] [PubMed]

33. Merz, J.; Schembecker, G.; Riemer, S.; Nimtz, M.; Zorn, H. Purification and identification of a novel cutinase from Coprinopsis. cinerea by adsorptive bubble separation. Sep. Purif. Technol. 2009, 69, 57-62. [CrossRef]

34. Kodama, Y.; Masaki, K.; Kondo, H.; Suzuki, M.; Tsuda, S.; Nagura, T.; Shimba, N.; Suzuki, E.; Iefuji, H. Crystal structure and enhanced activity of a cutinase-like enzyme from Cryptococcus sp. strain S-2. Proteins 2009, 77, 710-717. [CrossRef] [PubMed]

35. Dimarogona, M.; Nikolaivits, E.; Kanelli, M.; Christakopoulos, P.; Sandgren, M.; Topakas, E. Structural and functional studies of a Fusarium oxysporum cutinase with polyethylene terephthalate modification potential. Biochim. Biophys. Acta 2015, 1850, 2308-2317. [CrossRef] [PubMed]

36. Soliday, C.L.; Kolattukudy, P.E. Isolation and characterization of a cutinase from Fusarium roseum culmorum and its immunological comparison with cutinases from F. solani pisi. Arch. Biochem. Biophys. 1976, 176, 334-343. [CrossRef]

37. Longhi, S.; Czjzek, M.; Lamzin, V.; Nicolas, A.; Cambillau, C. Atomic resolution (1.0 A) crystal structure of Fusarium solani cutinase: Stereochemical analysis. J. Mol. Biol. 1997, 268, 779-799. [CrossRef] [PubMed]

38. Nyon, M.P.; Rice, D.W.; Berrisford, J.M.; Hounslow, A.M.; Moir, A.J.G.; Huang, H.; Nathan, S.; Mahadi, N.M.; Bakar, F.D.A.; Craven, C.J. Catalysis by Glomerella cingulata cutinase requires conformational cycling between the active and inactive states of its catalytic triad. J. Mol. Biol. 2009, 385, 226-235. [CrossRef] [PubMed]

39. Lin, T.S.; Kolattukudy, P.E. Structural studies on cutinase, a glycoprotein containing novel amino acids and glucuronic acid amide at the $\mathrm{N}$ terminus. Eur. J. Biochem. 1980, 106, 341-351. [CrossRef] [PubMed]

40. Kold, D.; Dauter, Z.; Laustsen, A.K.; Brzozowski, A.M.; Turkenburg, J.P.; Nielsen, A.D.; Kolds, H.; Petersen, E.; Schitt, B.; de Maria, L.; et al. Thermodynamic and structural investigation of the specific SDS binding of Humicola insolens cutinase. Protein Sci. 2014, 23, 1023-1035. [CrossRef] [PubMed]

41. Sweigard, J.A.; Chumley, F.G.; Valent, B. Disruption of a Magnaporthe grisea cutinase gene. Mol. Gen. Genet. 1992, 232, 183-190. [PubMed]

42. Wang, G.Y.; Michailides, T.J.; Hammock, B.D.; Lee, Y.M.; Bostock, R.M. Affinity purification and characterization of a cutinase from the fungal plant pathogen Monilinia fructicola (Wint.) honey. Arch. Biochem. Biophys. 2000, 382, 31-38. [CrossRef] [PubMed] 
43. Liebminger, S.; Eberl, A.; Sousa, F.; Heumann, S.; Fischer-Colbrie, G.; Cavaco-Paulo, A.; Guebitz, G.M. Hydrolysis of PET and bis-(benzoyloxyethyl) terephthalate with a new polyesterase from Penicillium citrinum. Biocatal. Biotransform. 2007, 25, 171-177. [CrossRef]

44. Sebastian, J.; Kolattukudy, P.E. Purification and characterization of cutinase from a fluorescent Pseudomonas putida bacterial strain isolated from phyllosphere. Arch. Biochem. Biophys. 1988, 263, 77-85. [CrossRef]

45. Davies, K.A.; Lorono, I.; Foster, S.J.; Li, D.; Johnstone, K.; Ashby, A.M. Evidence for a role of cutinase in pathogenicity of Pyrenopeziza brassicae on brassicas. Physiol. Mol. Plant Pathol. 2000, 57, 63-75. [CrossRef]

46. Parker, D.M.; Köller, W. Cutinase and other lipolytic esterases protect bean leaves from infection by Rhizoctonia solani. Mol. Plant Microbe Interact. 1998, 11, 514-522. [CrossRef]

47. Miyakawa, T.; Mizushima, H.; Ohtsuka, J.; Oda, M.; Kawai, F.; Tanokura, M. Structural basis for the $\mathrm{Ca}(2+)$-enhanced thermostability and activity of PET-degrading cutinase-like enzyme from Saccharomonospora viridis AHK190. Appl. Microbiol. Biotechnol. 2015, 99, 4297-4307. [CrossRef] [PubMed]

48. Kitadokoro, K.; Thumarat, U.; Nakamura, R.; Nishimura, K.; Karatani, H.; Suzuki, H.; Kawai, F. Crystal structure of cutinase Est119 from Thermobifida alba AHK119 that can degrade modified polyethylene terephthalate at $1.76 \AA$ resolution. Polym. Degrad. Stab. 2012, 97, 771-775. [CrossRef]

49. Roth, C.; Wei, R.; Oeser, T.; Then, J.; Foellner, C.; Zimmermann, W.; Straeter, N. Structural and functional studies on a thermostable polyethylene terephthalate degrading hydrolase from Thermobifida fusca. Appl. Microbiol. Biotechnol. 2014, 98, 7815-7823. [CrossRef] [PubMed]

50. Xu, H.; Yan, Q.; Duan, X.; Yang, S.; Jiang, Z. Characterization of an acidic cold-adapted cutinase from Thielavia terrestris and its application in flavor ester synthesis. Food Chem. 2015, 188, 439-445. [CrossRef] [PubMed]

51. Roussel, A.; Amara, S.; Nyyssola, A.; Mateos-Diaz, E.; Blangy, S.; Kontkanen, H.; Westerholm-Parvinen, A.; Carriere, F.; Cambillau, C. A Cutinase from Trichoderma reesei with a lid-covered active site and kinetic properties of true lipases. J. Mol. Biol. 2014, 426, 3757-3772. [CrossRef] [PubMed]

52. Maiti, I.B.; Kolattukudy, P.E.; Shaykh, M. Purification and characterization of a novel cutinase from nasturtium (Tropaeolum majus) pollen. Arch. Biochem. Biophys. 1979, 196, 412-423. [CrossRef]

53. Köller, W.; Parker, D.M. Purification and characterization of cutinase from Venturia inaequalis. Phytopathology 1989, 79, 278-283. [CrossRef]

54. Ferrario, V.; Ebert, C.; Knapic, L.; Fattor, D.; Basso, A.; Spizzo, P.; Gardossi, L. Conformational changes of lipases in aqueous media: A comparative computational study and experimental implications. Adv. Synth. Catal. 2011, 353, 2466-2480. [CrossRef]

55. Ferrario, V.; Siragusa, L.; Ebert, C.; Baroni, M.; Foscato, M.; Cruciani, G.; Gardossi, L. BioGPS descriptors for rational engineering of enzyme promiscuity and structure based bioinformatic analysis. PLoS ONE 2014, 9, e109354. [CrossRef] [PubMed]

56. Pellis, A.; Ferrario, V.; Cespugli, M.; Corici, L.; Guarnieri, A.; Zartl, B.; Herrero-Acero, E.; Ebert, C.; Guebitz, G.M.; Gardossi, L. Fully renewable polyesters via polycondensation catalyzed by Thermobifida cellulosilytica cutinase 1: An integrated approach. Green Chem. 2017. [CrossRef]

57. Farmer, T.J.; Castle, R.L.; Clark, J.H.; Macquarrie, D.J. Synthesis of unsaturated polyester resins from various bio-derived platform molecules. Int. J. Mol. Sci. 2015, 16, 14912-14932. [CrossRef] [PubMed]

58. Bassanini, I.; Hult, K.; Riva, S. Dicarboxylic esters: Useful tools for the biocatalyzed synthesis of hybrid compounds and polymers. Beilstein J. Org. Chem. 2015, 11, 1583-1595. [CrossRef] [PubMed]

59. Pellis, A.; Corici, L.; Sinigoi, L.; D’amelio, N.; Fattor, D.; Ferrario, V.; Ebert, C.; Gardossi, L. Towards feasible and scalable solvent-free enzymatic polycondensations: Integrating robust biocatalysts with thin film reactions. Green Chem. 2015, 17, 1756-1766. [CrossRef]

60. Hunsen, M.; Azim, A.; Mang, H.; Wallner, S.R.; Ronkvist, A.; Xie, W.; Gross, R.A. A cutinase with polyester synthesis activity. Macromolecules 2007, 40, 148-150. [CrossRef]

61. Feder, D.; Gross, R.A. Exploring chain length selectivity in HIC-catalyzed polycondensation reactions. Biomacromolecules 2010, 11, 690-697. [CrossRef] [PubMed]

62. Stavila, E.; Arsyi, R.Z.; Petrovic, D.M.; Loos, K. Fusarium solani pisi cutinase-catalyzed synthesis of polyamides. Eur. Polym. J. 2013, 49, 834-842. [CrossRef]

63. Stavila, E.; Alberda van Ekenstein, G.O.R.; Loos, K. Enzyme-catalyzed synthesis of aliphatic-aromatic oligoamides. Biomacromolecules 2013, 14, 1600-1606. [CrossRef] [PubMed] 
64. Binns, F.; Harffey, P.; Roberts, S.M.; Taylor, A. Studies leading to the large scale synthesis of polyesters using enzymes. J. Chem. Soc. Perkin Trans. 1999, 1, 2671-2676. [CrossRef]

65. Cantone, S.; Ferrario, V.; Corici, L.; Ebert, C.; Fattor, D.; Spizzo, P.; Gardossi, L. Efficient immobilisation of industrial biocatalysts: Criteria and constraints for the selection of organic polymeric carriers and immobilisation methods. Chem. Soc. Rev. 2013, 42, 6262-6276. [CrossRef] [PubMed]

66. Corici, L.; Ferrario, V.; Pellis, A.; Ebert, C.; Lotteria, S.; Cantone, S.; Voinovich, D.; Gardossi, L. Large scale applications of immobilized enzymes call for sustainable and inexpensive solutions: Rice husks as renewable alternatives to fossil-based organic resins. RSC Adv. 2016, 6, 63256-63270. [CrossRef]

67. Barth, M.; Oeser, T.; Wei, R.; Then, J.; Schmidt, J.; Zimmermann, W. Effect of hydrolysis products on the enzymatic degradation of polyethylene terephthalate nanoparticles by a polyester hydrolase from Thermobifida fusca. Biochem. Eng. J. 2015, 93, 222-228. [CrossRef]

68. Alisch-Mark, M.; Herrmann, A.; Zimmermann, W. Increase of the hydrophilicity of polyethylene terephthalate fibres by hydrolases from Thermomonospora fusca and Fusarium solanif. sp. pisi. Biotechnol. Lett. 2006, 28, 681-685. [CrossRef] [PubMed]

69. Donelli, I.; Taddei, P.; Smet, P.F.; Poelman, D.; Nierstrasz, V.A.; Freddi, G. Enzymatic surface modification and functionalization of PET: A water contact angle, FTIR, and fluorescence spectroscopy study. Biotechnol. Bioeng. 2009, 103, 845-856. [CrossRef] [PubMed]

70. Pellis, A.; Herrero Acero, E.; Weber, H.; Obersriebnig, M.; Breinbauer, R.; Srebotnik, E.; Guebitz, G.M. Biocatalyzed approach for the surface functionalization of poly(L-lactic acid) films using hydrolytic enzymes. Biotechnol. J. 2015, 10, 1739-1749. [CrossRef] [PubMed]

71. Mueller, R.J. Biological degradation of synthetic polyesters-ENZYMES as potential catalysts for polyester recycling. Proc. Biochem. 2006, 41, 2124-2128. [CrossRef]

72. Herrero Acero, E.; Ribitsch, D.; Steinkellner, G.; Gruber, K.; Greimel, K.; Eiteljoerg, I.; Trotscha, E.; Wei, R.; Zimmermann, W.; Zinn, M.; et al. Enzymatic surface hydrolysis of PET: Effect of structural diversity on kinetic properties of cutinases from Thermobifida. Macromolecules 2011, 44, 4632-4640. [CrossRef]

73. Pellis, A.; Gamerith, C.; Ghazaryan, G.; Ortner, A.; Herrero Acero, E.; Guebitz, G.M. Ultrasound-enhanced enzymatic hydrolysis of poly (ethylene terephthalate). Biores. Technol. 2016, 218, 1298-1302. [CrossRef] [PubMed]

74. Yang, S.; Xu, H.; Yan, Q.; Liu, Y.; Zhou, P.; Jiang, Z. A low molecular mass cutinase of Thielavia. terrestris efficiently hydrolyzes poly(esters). J. Ind. Microbiol. Biotechnol. 2013, 40, 217-226. [CrossRef] [PubMed]

75. Ronkvist, A.M.; Xie, W.; Lu, W.; Gross, R.A. Cutinase-catalyzed hydrolysis of poly(ethylene terephtalate). Maceomolecules 2009, 42, 5128-5138. [CrossRef]

76. Pellis, A.; Silvestrini, L.; Scaini, D.; Coburn, J.; Gardossi, L.; Kaplan, D.; Herrero Acero, E.; Guebitz, G.M. Enzyme-catalyzed functionalization of poly (L-lactic acid) for drug delivery applications. Process Biochem. 2016. [CrossRef]

77. Ribitsch, D.; Herrero Acero, E.; Greimel, K.; Dellacher, A.; Zitzenbacher, S.; Marold, A.; Diaz Rodriguez, R.; Steinkellner, G.; Gruber, K.; Schwab, H.; et al. A new esterase from Thermobifida halotolerans hydrolyses polyethylene terephthalate (PET) and polylactic acid (PLA). Polymers 2012, 4, 617-629. [CrossRef]

78. Pellis, A.; Haernvall, K.; Pichler, C.M.; Ghazaryan, G.; Breinbauer, R.; Guebitz, G.M. Enzymatic hydrolysis of poly (ethylene furanoate). J. Biotechnol. 2016, 235, 47-53. [CrossRef] [PubMed]

79. Perz, V.; Bleymaier, K.; Sinkel, C.; Kueper, U.; Bonnekessel, M.; Ribitsch, D.; Guebitz, G.M. Substrate specificities of cutinases on aliphatic-aromatic polyesters and on their model substrates. New Biotechnol. 2016, 33, 295-304. [CrossRef] [PubMed]

80. Silva, C.M.; Carnerio, F.; O’Neill, A.; Fonseca, L.P.; Cabral, J.S.M.; Guebitz, G.M.; Cavaco-Paulo, A. Cutinase-A new tool for biomodification of synthetic fibers. J. Polym. Sci. Part A Polym. Chem. 2005, 43, 2448-2450. [CrossRef]

81. Ribitsch, D.; Oracal Yebra, A.; Zitzenbacher, S.; Wu, J.; Nowitsch, S.; Steinkellner, G.; Greimel, K.; Doliska, A.; Oberdorfer, G.; Gruber, C.C.; et al. Fusion of binding domains to Thermobifida cellulosilytica cutinase to tune sorption characteristics and enhancing PET hydrolysis. Biomacromolecules 2013, 14, 1769-1776. [CrossRef] [PubMed]

82. Silva, C.; Da, S.; Silva, N.; Matamá, T.; Araújo, R.; Martins, M.; Chen, S.; Chen, J.; Wu, J.; Casal, M.; et al. Engineered Thermobifida fusca cutinase with increased activity on polyester substrates. Biotechnol. J. 2011, 6, 1230-1239. [CrossRef] [PubMed] 
83. Araújo, R.; Silva, C.; O’Neill, A.; Micaelo, N.; Guebitz, G.M.; Soares, C.M.; Casal, M.; Cavaco-Paulo, A. Tailoring cutinase activity towards polyethylene terephthalate and polyamide 6,6 fibers. J. Biotechnol. 2007, 128, 849-857. [CrossRef] [PubMed]

84. Bilal, M.H.; Prehm, M.; Njau, A.E.; Samiullah, M.H.; Meister, A.; Kressler, J. Enzymatic synthesis and characterization of hydrophilic sugar based polyesters and their modification with stearic acid. Polymers 2016, 8, 80. [CrossRef]

85. Clark, J.H.; Farmer, T.J.; Herrero-Davila, L.; Sherwood, J. Circular economy design considerations for research and process development in the chemical sciences. Green Chem. 2016, 18, 3914-3934. [CrossRef]

(C) 2016 by the authors; licensee MDPI, Basel, Switzerland. This article is an open access article distributed under the terms and conditions of the Creative Commons Attribution (CC-BY) license (http:/ / creativecommons.org/licenses/by/4.0/). 